\title{
Maize-N: A Decision Tool for Nitrogen Management in Maize
}

\author{
T. D. Setiyono, H. Yang, D. T. Walters, A. Dobermann, R. B. Ferguson, \\ D. F. Roberts, D. J. Lyon, D. E. Clay, and K. G. Cassman*
}

\begin{abstract}
Nitrogen fertilizer efficiency has a large influence on profit, energy efficiency, $\mathrm{N}$ losses to the environment, and greenhouse gas emissions in maize (Zea mays L.) production. Our purpose was to develop a robust decision-support tool to help inform $\mathrm{N}$ fertilizer recommendations and to compare performance of this tool relative to existing recommendation approaches. Maize- $\mathrm{N}$ is a simulation model for estimating economically optimum $\mathrm{N}$ fertilizer rates (EONR) for maize. The model estimates the EONR based on uptake efficiency of the applied $\mathrm{N}$, expected yield response, market prices of grain and $\mathrm{N}$ fertilizer, and mechanistic components of soil $\mathrm{N}$ mineralization. Uptake efficiency and expected yield response are derived from a database of yield response to applied $\mathrm{N}$ from field experiments in the United States, Asia, and South America. The model is responsive to: (i) soil properties and indigenous soil N supply capacity, (ii) local climatic conditions and yield potential, (iii) crop rotation (including type and yield of previous crop), (iv) tillage method and timing of tillage operations, and ( $v$ ) fertilizer formulation, application method, and timing. Validation of Maize- $N$ across $\mathrm{N}$ management regimes and environments in the western U.S. Corn Belt indicated reasonable agreement between observed and measured values of EONR (RMSE of $21 \mathrm{~kg} \mathrm{~N} \mathrm{ha}^{-1}$ ), which compares favorably with RMSE values of 33 to $61 \mathrm{~kg} \mathrm{~N} \mathrm{ha}^{-1}$ for other methods based on empirical relationships derived from regional field tests in Kansas, Missouri, Nebraska, South Dakota, and Iowa.
\end{abstract}

$\mathrm{O}$ PTIMIZING N FERTILIZER use in maize production is critical for maximizing profit and reducing $\mathrm{N}$ losses and associated negative environmental impacts. That an optimal solution is possible can be inferred from studies that have evaluated crop yield response and $\mathrm{N}$ losses across a wide range of $\mathrm{N}$ application rates. For example, Broadbent and Carlton (1978) found that $\mathrm{NO}_{3}$ leaching from irrigated maize was small when the rate of applied $\mathrm{N}$ fertilizer did not exceed requirements for $90 \%$ of maximum grain yield. Similarly, in a meta-analysis of $\mathrm{N}_{2} \mathrm{O}$ emissions from arable crops, van Groenigen et al. (2010) concluded that yield-scaled emissions were constant until $\mathrm{N}$ fertilizer inputs exceeded $\mathrm{N}$ uptake by the aboveground biomass. The EONR is the $\mathrm{N}$ rate at which no further increase in net return occurs, and this point on the response curve occurs well below maximum yield levels at grain and $\mathrm{N}$ fertilizer prices typical of the past $40 \mathrm{yr}$ (Dobermann et al., 2011).

In practice, the EONR is difficult to predict before planting because the actual shape of the yield response to applied $\mathrm{N}$ varies field to field, and year to year due to in-season weather and

T.D. Setiyono, D.T. Walters, R.B. Ferguson, and K.G. Cassman, Dep. of Agronomy and Horticulture, Univ. of Nebraska, Lincoln, NE 68583; H. Yang, Monsanto Company, 800 N. Lindbergh Blvd., St. Louis, MO 63167; A. Dobermann, IRRI, DAPO Box 7777, Metro Manila, Philippines 1301; D.F. Roberts, Dep. of Plant and Soil Sciences, Mississippi State Univ., Starkville, MS 39762; D.J. Lyon, Panhandle Research and Extension Center, Univ. of Nebraska-Lincoln, Scottsbluff, NE 69361; and D. Clay, Drought Center, South Dakota State Univ., Brookings, SD 57007. Received 8 Feb. 2011.

*Corresponding author (kcassman1@unl.edu).

Published in Agron. J. 103:1276-1283 (2011)

Posted online 8 Jun 2011

doi:10.2134/agronj2011.0053

Available freely online through the author-supported open access option. Copyright (c) 2011 by the American Society of Agronomy, 5585 Guilford Road, Madison, WI 53711. All rights reserved. No part of this periodical may be reproduced or transmitted in any form or by any means, electronic or mechanical, including photocopying, recording, or any information storage and retrieval system, without permission in writing from the publisher. crop management operations that influence the $\mathrm{N}$ supply-crop $\mathrm{N}$ demand balance. The EONR can be estimated by (i) the amount of $\mathrm{N}$ the crop obtains from the indigenous $\mathrm{N}$ supply (including $\mathrm{N}$ mineralization from organic matter, wet-dry deposition, and in irrigated systems, the $\mathrm{NO}_{3}-\mathrm{N}$ applied with irrigation), (ii) the shape of the $\mathrm{N}$ response function relating yield to the rate of $\mathrm{N}$ application, and (iii) prices for $\mathrm{N}$ fertilizer and maize grain. The shape of the yield response is determined by the yield potential when the crop is no longer limited by $\mathrm{N}$ (which defines the maximum attainable yield level), the agronomic fertilizer efficiency (AE, $\Delta$ yield/ $\Delta$ applied N), which in turn is determined by the efficiency of $\mathrm{N}$ uptake from the applied $\mathrm{N}$ (the recovery efficiency, RE) and the efficiency with which the acquired $\mathrm{N}$ is converted to grain yield (the physiological efficiency, PE) (Novoa and Loomis, 1981).

Despite the dynamic nature of the crop $\mathrm{N}$ response, extension programs in most U.S. Corn Belt states have established N fertilizer recommendations based on algorithms derived from regional field tests that do not directly account for fertilizer $\mathrm{N}$ use efficiency (Dobermann et al., 2006a). While such approaches can perform well in the region where they were developed, they may not be robust in other regions with different soils, climate, and crop rotations. Given the limitations of regional calibration and the high degree of temporal and spatial variability in factors affecting crop response to applied $\mathrm{N}$, new approaches that are responsive to this variability are under development.

One approach is to apply $\mathrm{N}$ in response to conditions during the growing season, such as in-season adjustment of the $\mathrm{N}$ application rate in relation to leaf or canopy $\mathrm{N}$ status using sensor technologies (Kitchen et al., 2010; Olfs et al., 2005) or a chlorophyll meter (Scharf et al., 2006). In-season adjustments can also be responsive to actual weather conditions that affect

Abbreviations: AE, agronomic efficiency; EONR, economically optimum nitrogen rate; ME, mean error; PE, physiological efficiency; RE, recovery efficiency; SOM soil organic matter. 


\begin{tabular}{|c|c|c|}
\hline Inputs & Processes & Outputs \\
\hline $\begin{array}{l}\text { - Long-term weather: daily } \\
\text { max. and min. air } \\
\text { temperature, solar } \\
\text { radiation } \\
\text { - Current maize crop: } \\
\text { maturity, planting date, } \\
\text { plant population, grain } \\
\text { price, yield history } \\
\text { (optional) } \\
\text { - Last crop: type, yield, } \\
\text { residue management } \\
\text { - Tillage: type \& time } \\
\text { - } \mathrm{N} \text { fertilizer: type, price, } \\
\text { number of applications, } \\
\text { timing } \\
\text { - Soil: Soil Organic Carbon } \\
\text { content (SOC), pH, } \\
\text { texture, bulk density } \\
\text { - Sooll nitrate before } \\
\text { planting (optional) } \\
\text { - Manure: type, amount, } \\
\text { timing }\end{array}$ & $\begin{array}{c}\text { Maize yield } \\
\text { \& variation } \\
\text { Hybrid-Maize model } \\
\text { Soil C \& N } \\
\text { mineralization } \\
\text { DK C \& N model } \\
\text { N use efficiencies } \\
\text { QUEEFTs, f(Y }\left(Y_{a}, Y_{0}\right) \\
\text { Maize yield } \\
\text { response to N rate }\end{array}$ & $\begin{array}{l}\text {-EONR } \\
\text { - Fertilizer amount } \\
\text { - Fertilizer cost } \\
\text { - } \mathrm{N} \text { use efficiencies } \\
\text { - Yield potential } \\
\text { - Attainable yield } \\
\text { - Total indigenous } \mathrm{N} \\
\text { uptake (IN) } \\
\text { - Contribution to IN from } \\
\mathrm{N} \text { carryover, SOC, } \\
\text { residues, manures, } \\
\text { and irrigation water } \\
\text { - Seasonal C \& N } \\
\text { mineralization } \\
\text { dynamics } \\
\text { - Interactive yield } \\
\text { response to } \mathrm{N} \text { rate }\end{array}$ \\
\hline
\end{tabular}

Fig. I. Inputs, processes, and outputs of the Maize- $\mathbf{N}$ model to determine the economically optimum $\mathrm{N}$ rate (EONR).

the $\mathrm{N}$ response (Moebius-Clune et al., 2009). In all of these approaches, a portion of the total $\mathrm{N}$ requirement is applied preplant and the rest in response to conditions during the growing season. While promising, each of these methods requires further development and validation to support widespread adoption.

Another approach is to use a simulation model that accounts for the dynamic interactions between management and environmental conditions to estimate $\mathrm{N}$ fertilizer requirements. Although some existing crop simulation models such as WOFOST (Supit and van der Goot, 2003) and Ceres-Maize (Jones and Kiniry, 1986) can be used for post-season evaluation of nutrient limitations in a maize crop, they were not designed to support preplant or in-season decisions about fertilizer $\mathrm{N}$ management. Given this situation, our objective was to develop and evaluate a simulation model for estimating maize $\mathrm{N}$ fertilizer requirements that is sensitive to the key factors governing the maize response to applied $\mathrm{N}$. The new model, called Maize-N, builds on the Hybrid-Maize model (Yang et al., 2004), which simulates maize growth and yield in response to climate and water supply. Maize-N extends to include sensitivity to factors governing soil $\mathrm{N}$ mineralization and the recovery of $\mathrm{N}$ fertilizer, while also accommodating differences in crop rotation, tillage practices, form of $\mathrm{N}$ fertilizer, method of application, and prices for grain and $\mathrm{N}$ fertilizer.

\section{MATERIALS AND METHODS}

\section{Model Development}

The Maize-N model consists of four components that estimate (i) maize yield potential, (ii) soil $\mathrm{C}$ and $\mathrm{N}$ mineralization, (iii) $\mathrm{N}$ use efficiencies, and (iv) yield vs. $\mathrm{N}$ response (Fig. 1). Inputs for the model consist of weather variables, management practices in the coming season for which the $\mathrm{N}$ rate is to be estimated (crop maturity, planting date, population, grain price, and yield history), previous season management (method of crop and residue management), $\mathrm{N}$ fertilizer practices including timing of application, and soil edaphic inputs. Optional inputs include residual soil $\mathrm{NO}_{3}$ before planting (if measured) and manure application (if applied). In addition to the EONR, Maize-N provides collateral outputs including estimated attainable yield, $\mathrm{N}$ uptake from indigenous soil sources, and the daily

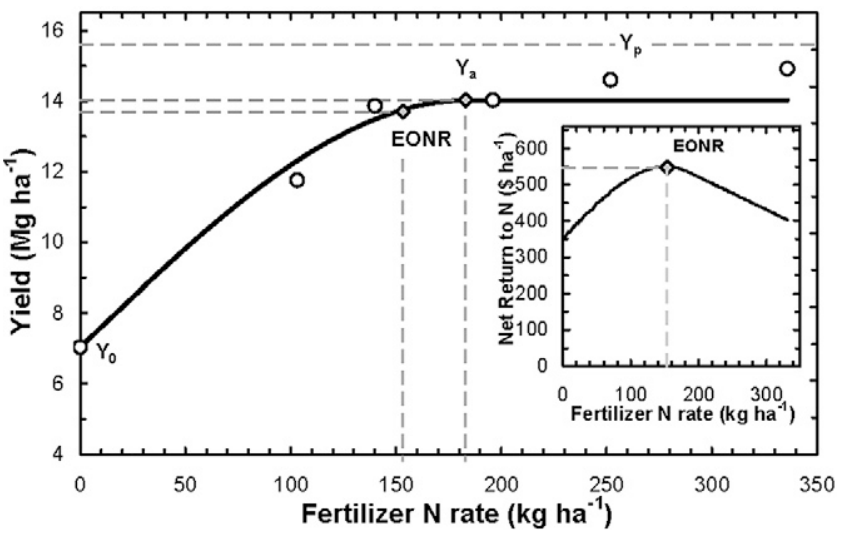

Fig. 2. Maize yield and fertilizer $\mathbf{N}$ rate as observed (symbols) and simulated with the spherical function used in the Maize-N model (solid line). The observed data are from the calibration data set from Clay Center, NE, in 2002. Yield potential $\left(Y_{p}\right)$ for the site was $15.6 \mathrm{Mg} \mathrm{ha}^{-1}$, attainable yield $\left(Y_{\mathrm{a}}\right)$ was $14 \mathrm{Mg} \mathrm{ha}^{-1}$, and yield without applied fertilizer $N\left(Y_{0}\right)$ was $7.0 \mathrm{Mg} \mathrm{ha}^{-1}$. The relationship between net return to $N$ and the fertilizer $N$ rate is shown in the inset with an economically optimum $\mathbf{N}$ rate (EONR) of $153 \mathrm{~kg} \mathrm{ha}^{-1}$, which corresponds to the maximum net return to $\mathrm{N}$ of US\$547 $\mathrm{ha}^{-1}$.

rate of $\mathrm{C}$ and $\mathrm{N}$ mineralization. All grain yields are based on standard grain moisture content $\left(0.155 \mathrm{~kg} \mathrm{H}_{2} \mathrm{O} \mathrm{kg}^{-1}\right.$ grain).

In Maize- $\mathrm{N}$, attainable yield $\left(Y_{\mathrm{a}}\right)$ is assumed to be a known fraction of the yield potential $\left(Y_{\mathrm{p}}\right)$ or can be supplied based on the yield history of a given site. For a given field, $Y_{\mathrm{p}}$ was estimated using the Hybrid-Maize model and long-term weather data from a nearby weather station (Yang et al., 2004). The weather data required to run Hybrid-Maize include daily values for maximum and minimum temperatures, solar radiation, and rainfall. The fraction $Y_{\mathrm{a}} / Y_{\mathrm{p}}$ is treated as an internal model parameter (user modifiable) with a default value of 0.85 . Because it is neither economical nor environmentally acceptable to provide the input levels required to achieve $100 \%$ of $Y_{\mathrm{p}}$, evidence from studies using on-farm data suggest that yield levels of 80 to $90 \%$ of $Y_{\mathrm{p}}$ can be attained in well-managed maize fields (Grassini et al., 2011). Thus, in Maize-N, $Y_{\mathrm{a}}$ defines the upper yield limit in the response to the rate of applied N (Fig. 2). A spherical function (Dobermann et al., 2006b) is used to relate yield to $\mathrm{N}$ rate:

$$
\begin{aligned}
Y=Y_{0}+b\left[\left(\frac{3}{2} \frac{N}{c}\right)-\right. & \left.\frac{1}{2}\left(\frac{N}{c}\right)^{3}\right] \\
& \text { if } N \geq c, Y=Y_{0}+b
\end{aligned}
$$

where $Y$ is the predicted maize yield $\left(\mathrm{Mg} \mathrm{ha}^{-1}\right), Y_{0}$ is the yield without applied fertilizer $\mathrm{N}\left(\mathrm{Mg} \mathrm{ha}^{-1}\right), N$ is the $\mathrm{N}$ rate $\left(\mathrm{kg} \mathrm{ha}^{-1}\right)$, $b$ is the difference between $Y_{\mathrm{a}}$ and $Y_{0}\left(\mathrm{Mg} \mathrm{ha}^{-1}\right)$, and $c$ is the $\mathrm{N}$ rate as the yield approaches $Y_{\mathrm{a}}\left(\mathrm{kg} \mathrm{ha}^{-1}\right)$. All yield terms are expressed as grain mass with $0.155 \mathrm{~kg} \mathrm{~kg}^{-1}$ moisture content.

In addition to $Y_{\mathfrak{a}}$, the yield without applied fertilizer $\mathrm{N}\left(Y_{0}\right)$ and $\mathrm{AE}$ also govern the shape of the spherical function of yield vs. $\mathrm{N}$ rate (Eq. [1]). The EONR is calculated by using the first derivative of the function relating net return to $\mathrm{N}$ and the $\mathrm{N}$ rate:

$$
\mathrm{EONR}=\sqrt{\frac{1.5 b c^{2}-\left(c^{3} / R\right)}{1.5 b}}
$$

where $R$ is price ratio of maize to $\mathrm{N}$ fertilizer (US\$ kg${ }^{-1}$ grain/ $\left.\mathrm{US} \$ \mathrm{~kg}^{-1} \mathrm{~N}\right)$.

The spherical yield response model of $\mathrm{N}$ rate provides a good fit to the actual $\mathrm{N}$ response, as shown in the example from Clay 


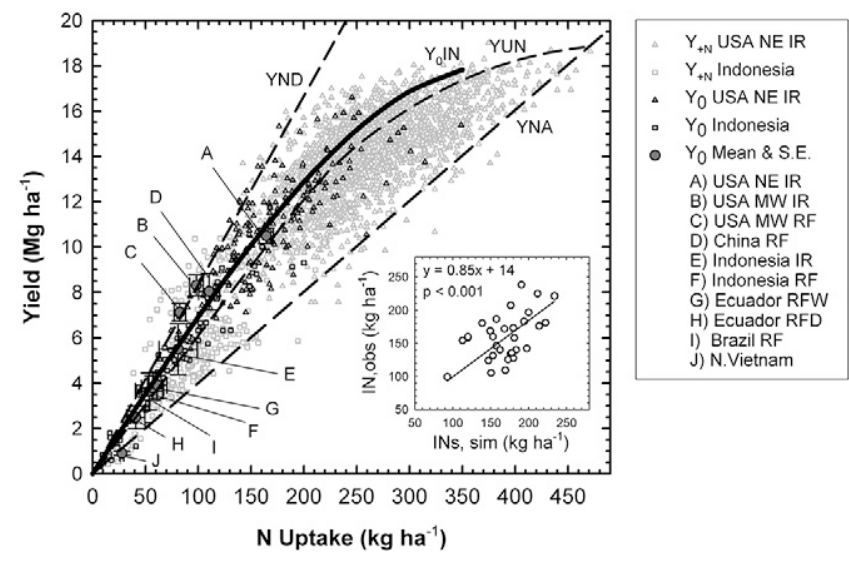

Fig. 3. Relationships between yield and $\mathbf{N}$ uptake in the global maize database used for the development of Maize-N. The relationship between observed indigenous $\mathbf{N}$ uptake (IN) and simulated indigenous $\mathbf{N}$ supply (INs) for the Nebraska irrigated (USA NE IR) data set is shown in the inset with a slope of 0.85 , which represents recovery efficiency of indigenous $\mathbf{N}$ and was used as a default value in the Maize- $\mathbf{N}$ model (MW, Midwest; IR, irrigated; RF, rainfed; RFW, rainfed wet season; RFD, rainfed dry season; $Y_{+N}$, yield with applied fertilizer $N$; $Y_{0}$, yield without applied $N$ fertilizer; $Y N D$, boundary line of maximum $\mathbf{N}$ dilution ( $\left.\mathrm{kg}_{\text {grain }} \mathrm{kg}^{-1} \mathrm{~N}\right)$; YNA, boundary line of maximum $\mathbf{N}$ accumulation ( $\mathrm{kg}_{\text {grain }} \mathbf{k g}^{-1} \mathbf{N}$ ); YUN and $Y_{0} I N$, yield vs. $N$ uptake for $Y_{+N}$ and $Y_{0}$, respectively, based on the QUEFTS model (Janssen et al., 1990).

Center, NE, in 2002 (Fig. 2). In this well-managed site, attainable yield reached $90 \%$ of $Y_{\mathrm{p}}$ and the estimated EONR was $153 \mathrm{~kg} \mathrm{~N} \mathrm{ha}^{-1}$ (actual EONR was $161 \mathrm{~kg} \mathrm{ha}^{-1}$ ). The observed and estimated EONR were based on a maize grain price of US $\$ 0.141 \mathrm{~kg}^{-1}$ (October 2009 price) (Economic Research Service, 2010b) and $\mathrm{N}$ price of $\$ 0.831 \mathrm{~kg}^{-1}$ (adjusted to an elemental $\mathrm{N}$ price from the actual price of $\mathrm{NH}_{4} \mathrm{NO}_{3}$ for March 2009) (Economic Research Service, 2010a).

Maize-N estimates $Y_{0}$ based on a generic yield vs. N uptake relationship for indigenous $\mathrm{N}$ sources (Fig. 3) determined using the QUEFTS approach (Janssen et al., 1990) from a global maize database that includes measurements of yield and $\mathrm{N}$ uptake taken from field experiments conducted at research stations and in farmer's fields in Nebraska in the United States, Indonesia and Vietnam (Setiyono et al., 2010), and Brazil, Ecuador, and China (provided by L. Prochnow, J. Espinosa, and P. He, International Plant Nutrition Institute, Brazil, northern Latin America, and north-central China, respectively). It was assumed that the uptake efficiency of indigenous $\mathrm{N}$ sources was 0.85 , as shown by the slope of observed indigenous $\mathrm{N}$ vs. simulated $\mathrm{N}$ supply for the irrigated field experiments in Nebraska (Fig. 3, insert). The indigenous N supply is calculated mechanistically using the $\mathrm{C}$ and $\mathrm{N}$ mineralization subroutine (DK C\&N model, Yang and Janssen, 2000), which is responsive to soil temperature, as estimated from air temperature, and tillage. The tillage system affects the amount of crop residue returned to the soil such that mineralization is greater with conventional tillage methods and less under notill. The amount of crop residue is estimated based on the yield of the previous crop and the crop species, which are inputs to the model, and a default $\mathrm{C} / \mathrm{N}$ ratio and harvest index for each crop species. Once indigenous $\mathrm{N}$ uptake is known, the yield without applied $\mathrm{N}$ is then calculated using the cubic solver for $\mathrm{N}$ uptake vs. yield (Setiyono et al., 2010).

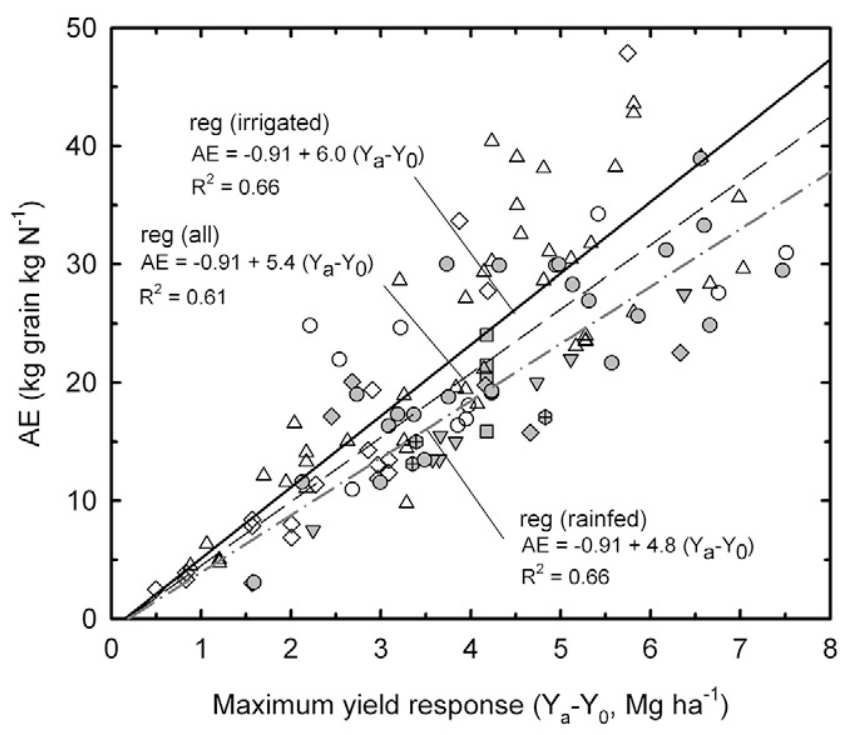

\begin{tabular}{|ll|}
\hline$\square$ & North Vietnam \\
$\diamond$ & Indonesia IR \& RF \\
$\Delta$ & USA NE IR \\
$\oplus$ & China RF \\
$\diamond$ & Brazil RF \\
$\nabla$ & Ecuador RF \\
0 & USA MW IR \\
0 & USA MW RF \\
\hline
\end{tabular}

Fig. 4. Relationship between agronomic efficiency (AE) and maximum yield response $\left(Y_{\mathrm{a}}-Y_{0}\right.$, where $Y_{\mathrm{a}}$ is attainable yield and $Y_{0}$ is yield without $\mathbf{N}$ fertilizer) to applied $\mathbf{N}$ at each site in the global maize database. The overall regression equation (for both irrigated, IR, and rainfed, RF, environments) is used in the Maize- $\mathbf{N}$ model to determine a baseline AE for a given environment. This baseline AE is then modified by climate, soil properties, and crop and soil management practices that influence the recovery efficiency of applied fertilizer $\mathbf{N}$ and the physiological efficiency of converting acquired $\mathbf{N}$ to yield.

Three different but related aspects of $\mathrm{N}$ use efficiency are used in Maize-N. First, AE is empirically determined based on its linear relationship to the maximum yield response to applied $\mathrm{N}$ $\left(Y_{\mathrm{a}}-Y_{0}\right)$ (Fig. 4). Although there was a slight difference in the slope of the regression between the irrigated and rainfed data sets (Fig. 4), the combined slope was used in Maize- $\mathrm{N}$ to give a "baseline" $\mathrm{AE}$ as estimated by the combined regression line, because $\mathrm{AE}=\mathrm{PE} \times \mathrm{RE}$, where $\mathrm{PE}$ is physiological efficiency of $\mathrm{N}$ uptake ( $\Delta \mathrm{kg}$ grain $/ \Delta \mathrm{kg} \mathrm{N}$ uptake) and $\mathrm{RE}$ is the recovery efficiency of applied fertilizer $\mathrm{N}(\Delta \mathrm{kg} \mathrm{N}$ uptake/ $\mathrm{kg} \mathrm{N}$ applied). In Maize-N, the baseline AE is then sensitive to weather factors influencing the crop yield level, which affects the PE, as shown in Fig. 3, and soil and fertilizer management factors that influence the RE, such as fertilizer formulation, application method, and soil texture (Cassman et al., 2002; Inman et al., 2005; Fageria and Baligar, 2005). Soil and fertilizer management options are specified as inputs to a simulation.

\section{Model Validation}

The Maize-N model was validated using data from wellmanaged field experiments conducted in central Nebraska (Roberts, 2009), eastern South Dakota (Kim et al., 2008), and western Nebraska (Blumenthal et al., 2003) (Table 1). The locations included both irrigated (central Nebraska and eastern South Dakota) and rainfed (eastern South Dakota and western Nebraska) systems. For each site and year, weeds, insect pests, 
Table I. Description of data sets ${ }^{\dagger}$ used for validation of the Maize-N model to determine the economically optimum $\mathbf{N}$ rate (EONR).

\begin{tabular}{|c|c|c|c|c|c|c|c|c|}
\hline Data set & Location, year & Location & $\begin{array}{l}\text { Tillage } \ddagger \text {, soil series, } \\
\text { previous crop }\end{array}$ & $\begin{array}{c}\text { Soil } \\
\text { organic C§ }\end{array}$ & Hybridף & $\begin{array}{c}\text { Plant } \\
\text { population }\end{array}$ & $\begin{array}{l}\text { Measured } \\
\text { yield\# }\end{array}$ & $\begin{array}{c}\text { Observed } \\
\text { EONR }\end{array}$ \\
\hline & & lat., long. & & $\%$ & & plants $\mathrm{m}^{-2}$ & $\mathrm{Mg} \mathrm{ha}^{-1}$ & $\mathrm{~kg} \mathrm{ha}^{-1}$ \\
\hline \multirow[t]{4}{*}{$\begin{array}{l}\text { Central Nebraska } \\
\text { (Roberts, 2009) }\end{array}$} & Merrick County, 2007 & 4I.277, -97.992 & $\begin{array}{l}\text { NT, Ipage loamy fine } \\
\text { sand, soybean }\end{array}$ & $0.68,0.86$ & P33N08 & 6.6 & $11.3-12.1$ & $172-202$ \\
\hline & Merrick County, 2008 & $41.257,-98.015$ & $\begin{array}{l}\text { NT, Thurman loamy } \\
\text { fine sand, soybean }\end{array}$ & $0.91,1.33$ & P34R67 & 6.7 & $10.7-\mid 5.1$ & $127-235$ \\
\hline & Hamilton County, 2007 & $40.775,-98.123$ & $\begin{array}{l}\text { RT, Crete silt loam, } \\
\text { maize }\end{array}$ & $1.75,2.03$ & P34R67 & 6.7 & $13.8-\mid 4.5$ & $107-148$ \\
\hline & Hamilton County, 2008 & $40.803,-98.219$ & $\begin{array}{l}\text { RT, Hasting silty clay } \\
\text { loam, popcorn }\end{array}$ & $0.87,0.87$ & HH NG6783 & 6.7 & $11.9-14.3$ & $219-245$ \\
\hline $\begin{array}{l}\text { Eastern South Dakota } \\
\text { (Kim et al., 2008) }\end{array}$ & $\begin{array}{l}\text { Aurora, 2002, 2003, } 2004 \\
\text { (each with irrigation and } \\
\text { rainfed treatments) }\end{array}$ & $44.300,-96.667$ & $\begin{array}{l}\text { NT, Brandt silty clay } \\
\text { loam, soybean-wheat }\end{array}$ & 2.51 & $\begin{array}{c}\text { DK } \\
44-46 R R\end{array}$ & 6.8 & $8.7-10.8$ & $116-129$ \\
\hline \multirow{4}{*}{$\begin{array}{l}\text { Western Nebraska } \\
\text { (Blumenthal et al., } \\
\text { 2003) }\end{array}$} & Banner County, 1999 & $41.583,-103.452$ & $\begin{array}{l}\text { NT, Tripp very fine } \\
\text { sandy loam, wheat }\end{array}$ & 0.70 & P3893 & 5.7 & 6.3 & 89 \\
\hline & Box Butte County, I999 & $42.157,-103.208$ & $\begin{array}{l}\text { NT, Creighton very fine } \\
\text { sandy loam, wheat }\end{array}$ & 0.64 & P3893 & 5.7 & 4.0 & 107 \\
\hline & Cheyenne County, 1999 & $41.231,-103.020$ & $\begin{array}{c}\text { NT, Duroc loam, } \\
\text { wheat }\end{array}$ & 1.83 & P3893 & 4.7 & 6.5 & 67 \\
\hline & Box Butte County, 2000 & $42.147,-103.184$ & $\begin{array}{c}\text { NT,Alliance loam, } \\
\text { wheat }\end{array}$ & 0.68 & P3893 & 3.7 & 3.8 & 79 \\
\hline
\end{tabular}

† Data were not used in model development and calibration of Maize-N; number of observations $(n)=18$.

$\ddagger N T$, no-till; $R T$, ridge tillage.

$\S$ Two values for soil organic $\mathrm{C}$ (SOC) at the central Nebraska sites represent SOC levels in two distinct soil zones within the experimental sites.

II P, Pioneer; HH, Heartland Hybrid; DK, DeKalb.

\# Measured yield from the treatment with the highest yield in well-managed field experiments.

Table 2. Maize $\mathbf{N}$ fertilizer recommendation methods used in different states and regions of the Corn Belt.

\begin{tabular}{|c|c|c|}
\hline Approach & $\mathbf{N}$ rate determination & Reference \\
\hline $\begin{array}{l}\text { University of Nebraska- } \\
\text { Lincoln (UNL) }\end{array}$ & $\begin{array}{l}\text { Empirically based on expected yield, inorganic soil } \mathrm{N} \text { (residual soil } \mathrm{NO}_{3} \text { based on soil test } \\
\text { analysis), soil } \mathrm{N} \text { supply from organic matter, and } \mathrm{N} \text { credits from previous crops and manure } \\
\text { applications. Slope of } \mathrm{N} \text { rate vs. expected yield is } 67.2 \mathrm{~kg} \text { grain } \mathrm{kg}^{-1} \mathrm{~N}\left(1.2 \text { bu grain } \mathrm{lb}^{-1} \mathrm{~N}\right)\end{array}$ & $\begin{array}{l}\text { Shapiro et al. } \\
\text { (2008) }\end{array}$ \\
\hline Kansas State University & $\begin{array}{l}\text { Similar to UNL approach but with greater sensitivity of } \mathrm{N} \text { rate to changes in expected yield. } \\
\text { Also takes into account the profile depth of residual soil } \mathrm{NO}_{3} \text { measurement. Slope of } \mathrm{N} \text { rate } \\
\text { vs. expected yield is } 89.6 \mathrm{~kg}^{-} \text {grain kg } \mathrm{kg}^{-1} \mathrm{~N}\left(1.6 \text { bu grain } \mathrm{Ib}^{-1} \mathrm{~N}\right)\end{array}$ & $\begin{array}{l}\text { Leikam et al. } \\
\quad(2003)\end{array}$ \\
\hline $\begin{array}{l}\text { South Dakota State } \\
\text { University }\end{array}$ & $\begin{array}{l}\left.\text { Empirically based on expected yield, inorganic soil } \mathrm{N} \text { (residual soil } \mathrm{NO}_{3}\right) \text {, and } \mathrm{N} \text { credits from } \\
\text { previous crops and manure applications. Does not take into account soil } \mathrm{N} \text { supply from } \\
\left.\text { organic matter. Slope of } \mathrm{N} \text { rate vs. expected yield is } 50.4 \mathrm{~kg}^{\text {grain } \mathrm{kg}^{-1} \mathrm{~N}(0.9 \text { bu lb }} \mathrm{lb}^{-1} \mathrm{~N}\right)\end{array}$ & $\begin{array}{l}\text { Gerwing and Gelderman } \\
\qquad(2005)\end{array}$ \\
\hline University of Missouri & $\begin{array}{l}\text { Empirically based on expected yield, plant population density, soil } \mathrm{N} \text { supply from organic matter, } \\
\text { and } \mathrm{N} \text { credits from previous crops and manure applications. Does not require inorganic soil } \mathrm{N} \\
\text { test. Slope of } \mathrm{N} \text { rate vs. expected yield is } 50.4 \mathrm{~kg} \text { grain } \mathrm{kg}^{-1} \mathrm{~N}\left(0.9 \text { bu grain } \mathrm{lb}^{-1} \mathrm{~N}\right)\end{array}$ & $\begin{array}{l}\text { Brown et al. } \\
\quad(2004)\end{array}$ \\
\hline
\end{tabular}

and diseases were effectively controlled, and nutrients other than $\mathrm{N}$ were in adequate supply. Only the highest yielding treatments were used in the validation. Measured yields and EONR at the central Nebraska sites varied due to two distinct soil types with different levels of soil organic $\mathrm{C}$ within each field (Roberts, 2009); in eastern South Dakota, measured yield and EONR varied due to different water management regimes (irrigated vs. rainfed). In western Nebraska, the experiments were conducted under rainfed conditions and yields were constrained by the water supply. For each of these experiments, $Y_{\mathrm{p}}$ was simulated for the field studies based on actual planting date, hybrid maturity, plant density, and weather data.

The Maize-N performance in simulating the EONR was compared against existing algorithms developed by (i) the University of Nebraska-Lincoln (Shapiro et al., 2008), (ii) Kansas State University (Leikam et al., 2003), (iii) South Dakota State University (Gerwing and Gelderman, 2005), and (iv) the University of Missouri (Brown et al., 2004). Brief descriptions of these $\mathrm{N}$ recommendation schemes are shown in
Table 2, while detailed equations for EONR determinations with each of these approaches are given in the appendix. Each of these $\mathrm{N}$ fertilizer recommendation methods are empirical in nature and derived from a large database of field experiments conducted within the respective state or region. At each testing site, the maize response to applied $\mathrm{N}$ fertilizer was tested across a range of $\mathrm{N}$ rates to allow estimation of the EONR. The individual state-level recommendations for Kansas, Missouri, Nebraska, and South Dakota are based on algorithms sensitive to the expected yield level and varying levels of detail about soil properties and crop and soil management. While most of the information required to use these algorithms is easily obtained or known by the crop producer before planting, determination of the yield goal requires knowledge of $Y_{\mathrm{p}}$ at a given site. In Maize-N, the yield goal is estimated by the Hybrid-Maize model, either as a stand-alone program for the rainfed sites or as an embedded function within the Maize- $\mathrm{N}$ model for the irrigated sites. The yield goal for a given site in Maize-N was determined $\left(Y_{\mathrm{a}}=0.85 Y_{\mathrm{p}}\right)$ as mentioned above. 


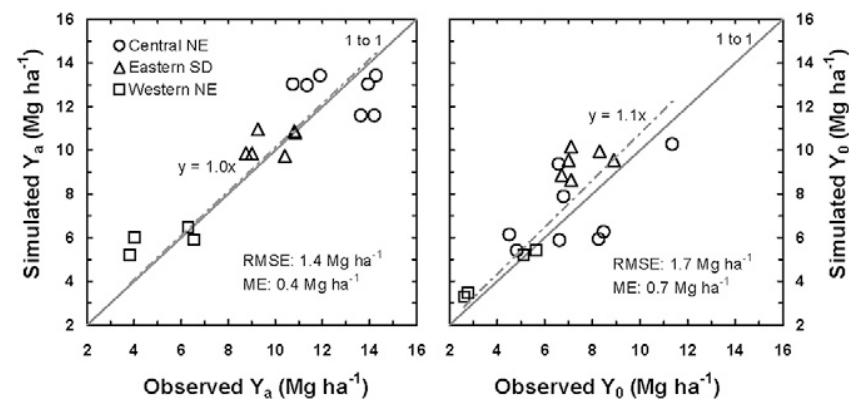

Fig. 5. Attainable maize grain yield $\left(Y_{\mathrm{a}}\right)$ (left panel) and yield without applied fertilizer $\mathbf{N}\left(Y_{0}\right)$ (right panel) as observed and simulated with the Hybrid-Maize model. Observed data (18 site-year observations) included locations in central Nebraska (Roberts, 2009), eastern South Dakota (Kim et al., 2008), and western Nebraska (Blumenthal et al., 2003). Simulated $Y_{\text {a }}$ and $Y_{0}$ values are associated with simulation of the economically optimum $\mathbf{N}$ rate in Fig. I.

The RMSE and mean error (ME) were calculated for the simulated values from all methods of estimating the EONR following the methods given by Janssen and Heuberger (1995):

$$
\begin{aligned}
& \mathrm{RMSE}=\sqrt{\frac{\sum\left(s_{i}-o_{i}\right)^{2}}{n}} \\
& \mathrm{ME}=\frac{\sum\left(s_{i}-o_{i}\right)}{n}
\end{aligned}
$$

where $s_{i}$ is the simulated data for the $i$ th site-year-zone or treatment combination (experimental unit), $o_{i}$ is the observed data for the $i$ th experimental unit, and $n$ is the number of pairs of simulated and observed data.

\section{RESULTS}

The Hybrid-Maize model simulated attainable yields $\left(Y_{\mathrm{a}}\right)$ at the validation sites with a RMSE of 1.4 and ME of $0.4 \mathrm{Mg} \mathrm{ha}^{-1}$ (Fig. 5). These simulations were considered robust given the large range of observed yields from 3.8 to $15.1 \mathrm{Mg} \mathrm{ha}^{-1}$ in this study. More importantly, there is no systematic trend of under- or overestimation of simulated yield across the observed yields. The RMSE for the simulation of $Y_{0}$ was $1.7 \mathrm{Mg} \mathrm{ha}^{-1}$, with a $\mathrm{ME}$ of $0.70 \mathrm{Mg} \mathrm{ha}^{-1}$. Similar to $Y_{\mathrm{a}}$, there was little bias in estimating $Y_{0}$ across the range of observed yields.

Using the validation data set, the EONR estimated by each $\mathrm{N}$ fertilizer recommendation method shown in Table 2, as well as by Maize-N, were compared with the actual observed values (Fig. 6). The Maize-N model estimated the EONR with greater accuracy than the more empirical $\mathrm{N}$ recommendation approaches, with RMSE and ME values of 21 and $10 \mathrm{~kg} \mathrm{ha}^{-1}$. Among the state algorithm-based $\mathrm{N}$ recommendation methods, the South Dakota algorithm had the lowest RMSE of $33 \mathrm{~kg} \mathrm{ha}^{-1}$, while the Missouri algorithm had the highest RMSE of $61 \mathrm{~kg} \mathrm{ha}^{-1}$.

The accuracy of EONR simulation with yield-goal-based state $\mathrm{N}$ recommendation schemes appeared to vary by region. For example, EONR simulation with the University of Nebraska-Lincoln algorithm was more accurate for central and western Nebraska but was not robust for the South Dakota site. Similarly, the South Dakota algorithm was generally more accurate for the South Dakota and western Nebraska sites but not robust for the central Nebraska sites. On the other hand,
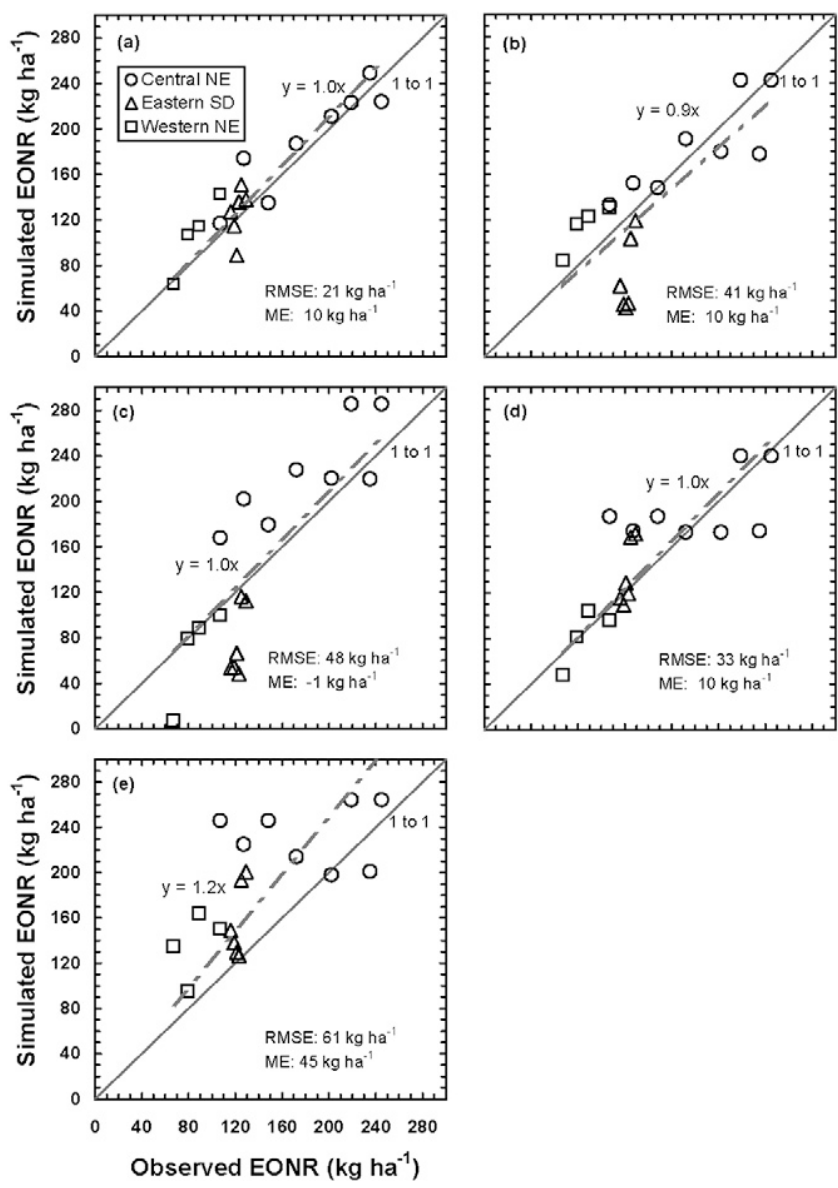

Fig. 6. Economically optimum $\mathbf{N}$ rate (EONR) as observed and simulated with (a) the Maize- $\mathrm{N}$ model (this study) and various yield-goal-based algorithms: (b) University of NebraskaLincoln (Shapiro et al., 2008); (c) Kansas State University (Leikam et al., 2003); (d) South Dakota State University (Gerwing and Gelderman, 2005); and (e) University of Missouri (Brown et al., 2004). The observed data (18 site-year observations) were independent of Maize- $\mathbf{N}$ model calibration and included locations in central Nebraska (Roberts, 2009), eastern South Dakota (Kim et al., 2008), and western Nebraska (Blumenthal et al., 2003).

Maize-N showed relatively robust EONR simulation across the different sites in the validation data set (Fig. 6).

Simulation of the EONR with Maize-N was sensitive to factors that decrease either crop $\mathrm{N}$ demand or the indigenous soil $\mathrm{N}$ supply from the baseline values. For example, the EONR was reduced as $Y_{\mathrm{a}}$ decreased from a baseline at the South Dakota and central Nebraska validation sites (Fig. 7a and 7b). Likewise, the EONR decreased with greater soil organic C (SOC) than the baseline, which increases the indigenous $\mathrm{N}$ supply (Fig. $7 \mathrm{c}$ and $7 \mathrm{~d}$ ). On the contrary, an increase in $Y_{\mathrm{a}}$ or reduction in SOC relative to the baseline resulted in a relatively moderate increase in the simulated EONR. In Fig. 7, the sharp decline in simulated EONR is especially evident when the simulated $Y_{0}$ approaches $Y_{\mathrm{a}}$, where the model suggests that no additional $\mathrm{N}$ fertilizer was needed for the maize crop. The responses of the EONR to SOC and $Y_{\mathrm{a}}$ were also influenced interactively by previous crop and tillage operations (Fig. 7). Generally, the system became more sensitive to changes in SOC or $Y_{\mathrm{a}}$ when soybean [Glycine max (L.) Merr.] was the previous crop and with conventional tillage, compared with when maize was the previous crop in no-till systems. 


\section{DISCUSSION}

This study, as well as others (Timsina et al., 2010; Ping et al., 2008; Grassini et al., 2011), has found the Hybrid-Maize model to be robust in estimating maize yield potential across a wide range of environments. Attainable yields at the validation sites were site specific and influenced by climate, agronomic management, and water supply. The highest maize yields were observed and simulated by Hybrid-Maize in the irrigated systems of central Nebraska (Fig. 5). The lowest maize yields were observed and simulated for the rainfed sites in western Nebraska. Irrigated and rainfed yields in South Dakota were intermediate to the two Nebraska sites for both observed and simulated yields. A reliable estimate of $Y_{\mathrm{p}}$ is crucial for tactical $\mathrm{N}$ management because it sets the upper ceiling on both yield and $\mathrm{N}$ uptake requirements at a given site.

While climate and water availability are key factors determining attainable yields across sites, the yield without applied $\mathrm{N}\left(Y_{0}\right)$ also relies on edaphic, climatic, and management factors influencing the indigenous $\mathrm{N}$ supply. This sensitivity makes it difficult to estimate $Y_{0}$ at the beginning of a growing season. Hence, estimates of $Y_{0}$ by Maize-N were less accurate than estimates of $Y_{a}$, based on simulation of $Y_{\mathrm{p}}$ with Hybrid-Maize (Fig. 5). Improving the estimation of $Y_{0}$ might be possible by revising Maize-N to account for additional factors influencing $\mathrm{N}$ mineralization or by simulation with real-time weather data (instead of long-term weather data). It is notable that the delta yield $\left(Y_{\mathrm{a}}-Y_{0}\right)$ as used in Maize-N appears to be more robust in estimating the EONR than the yield goal as used in other studies (Lory and Scharf, 2003).

The existing approaches for tactical fertilizer $\mathrm{N}$ requirements were considerably less accurate in predicting EONR than Maize-N. These methods were developed for a specific state or region and were not intended to be generic in scope. But for maize producers in border regions such as eastern Nebraska, southeast South Dakota, northwest Missouri, or northeast Kansas, it is not clear which statewide recommendation would work best. In contrast, Maize-N is based on fundamental relationships that govern $\mathrm{N}$ availability and crop demand as affected by management and environment. We speculate that these relationships should hold true across a wide range of environments. Further testing of Maize-N is needed across a much larger range of conditions, including sites throughout the Corn Belt and globally, to test this hypothesis.

Fertilizer $\mathrm{N}$ requirements are more difficult to estimate in regions where average maize yields are low due to water deficits and large year-to-year variation in rainfall because the annual variation in $Y_{\mathrm{p}}$ is large. In regions where the average maize yields are low due to water deficits and large year-to-year variation in rainfall, the degree of uncertainty can be reduced if the soil moisture at planting is known (Lyon et al., 2003). Although Maize-N does not currently allow input of the soil moisture status at planting, the Hybrid-Maize model has this capacity. Thus, yield goals designated in Maize-N and associated EONR values for low-yield, water-limited environments would benefit from specification of the initial soil moisture at planting. The use of split $\mathrm{N}$ fertilizer applications may also make sense under these conditions so that the yield goal can be refined as more information becomes available about rainfall and soil moisture storage at planting and during the crop establishment phase.

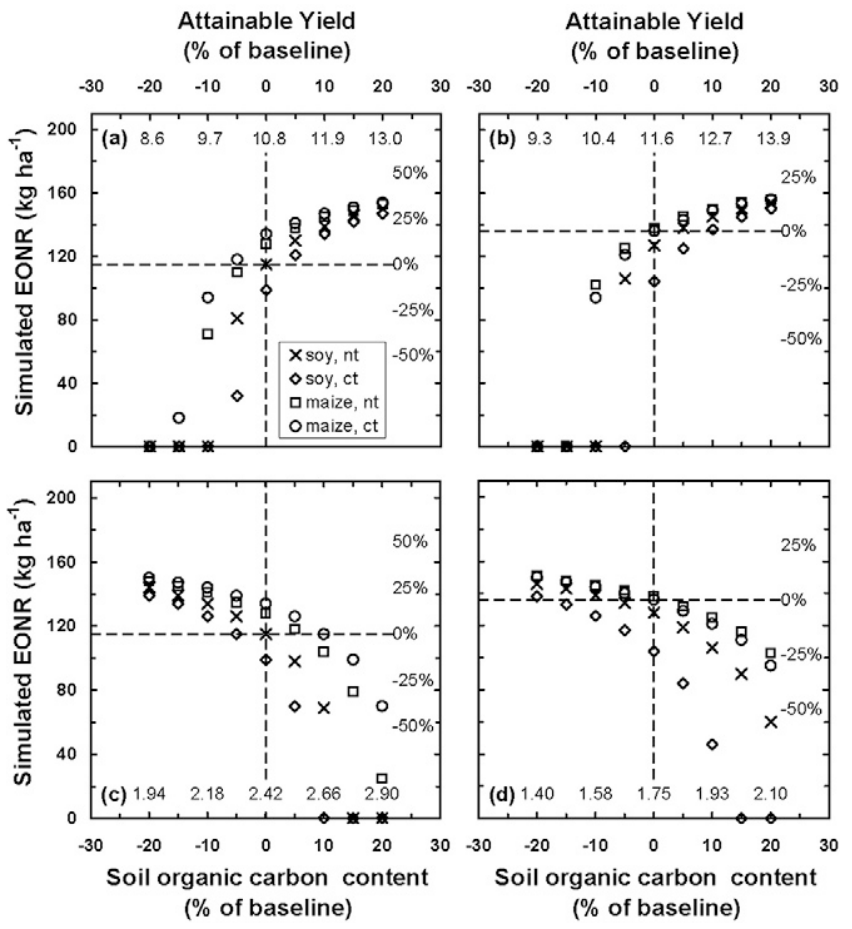

Fig. 7. Sensitivity of the economically optimum $\mathbf{N}$ rate (EONR) to (a and b) attainable yield, $Y_{\mathrm{a}}$, and (c and d) soil organic $C$, SOC, as simulated by Maize-N. Two baseline cases are shown: (a and c) an eastern South Dakota site (Brookings, SD) with $Y_{a}$ of $10.8 \mathrm{Mg} \mathrm{ha}^{-1}, 2.42 \% \mathrm{SOC}$, a previous crop of soybean (soy), and no-till management (nt), and (b and d) a central Nebraska site (Clay Center, NE) with $Y_{\mathrm{a}}$ of $11.6 \mathrm{Mg} \mathrm{ha}^{-1}, \mathrm{I.75} \% \mathrm{SOC}$, a previous crop of maize, and conventional tillage (ct). Sensitivity tests included counterpart options for soil management (no-till vs. conventional tillage) and the previous crop (maize vs. soybean) at each site, as shown by the different symbols. Vertical and horizontal dotted lines indicate baseline values for SOC and simulated EONR, respectively. For reference purpose, the values of $Y_{\mathrm{a}}$ and SOC associated with the various percentages of $Y_{\mathrm{a}}$ and SOC are shown near the horizontal axis at the top and bottom of each panel. Similarly, the percentage increase or decrease in EONR above or below the baseline is shown on the right side of each panel.

The main difficulty of estimating the EONR before a growing season is due to the unpredictable actual weather, particularly rainfall and temperature, and their impact on soil $\mathrm{N}$ mineralization and loss processes such as $\mathrm{NH}_{3}$ volatilization, denitrification, and leaching. These uncertainties were emphasized as important factors governing the estimation of $\mathrm{N}$ fertilizer rate in the Adaptive- $\mathrm{N}$ model for corn production (Moebius-Clune et al., 2009), and they also have a large influence on optimal $\mathrm{N}$ fertilizer rates in rice (Oryza sativa L.) cropping systems (Cassman et al., 1996). Given the variability in weather and the susceptibility of inorganic $\mathrm{N}$ from soil and fertilizer to various loss processes, the accuracy of $\mathrm{N}$ fertilizer requirements before planting will always have a degree of uncertainty. Nonetheless, preseason $\mathrm{N}$ estimation by Maize-N is a useful tool for production systems in which it is not possible to apply more than one or two $\mathrm{N}$ applications. Maize- $\mathrm{N}$ is also useful for scenario analysis to evaluate the impact of different crop and soil management options and associated influences on $\mathrm{N}$ fertilizer efficiency in a specific cropping system defined by its environment, which includes soil type and climate, and by crop rotation, residue management, and tillage system. 
Table AI. Soil N credits based on soil texture and organic matter content.

\begin{tabular}{rcc}
\hline Soil texture & Organic matter & Soil N credit $†$ \\
\hline \multirow{2}{*}{ Sand-sandy loam } & $\%$ & $\mathrm{lb} \mathrm{N} \mathrm{acre}^{-1}$ \\
& $\leq 0.5$ & 20 \\
Silt loam-loam & $0.6-1.4$ & 40 \\
& $\geq 1.5$ & 60 \\
& $\leq 2.0$ & 40 \\
Clay loam-clay & $2.1-3.9$ & 20 \\
& $\geq 4.0$ & 80 \\
& $\leq 2.0$ & 20 \\
& $2.1-4.9$ & 10 \\
\hline
\end{tabular}

† Multiply values by 1.12 to convert data to $\mathrm{kg} \mathrm{ha}^{-1}$.

\section{APPENDIX}

Existing approaches for $\mathrm{N}$ fertilizer recommendation $\left(N_{\mathrm{f}}\right)$ for maize:

1. University of Nebraska (Shapiro et al., 2008):

$$
\begin{aligned}
N_{\mathrm{f}}=f_{\mathrm{m}} & {\left[35+1.2 \mathrm{EY}-8 \mathrm{NO}_{3}\right.} \\
- & \left.0.14(\mathrm{EY}) \mathrm{SOM}-N_{\text {credit }}\right]
\end{aligned}
$$

2. Kansas State University (Leikam et al., 2003):

$$
\begin{aligned}
N_{\mathrm{f}}=f_{\mathrm{m}}(1.6 \mathrm{EY}- & 0.3 \mathrm{DNO}_{3} \\
- & \left.20 \mathrm{SOM}-N_{\text {credit }}\right)
\end{aligned}
$$

3. South Dakota State University (Gerwing and Gelderman, 2005):

$$
N_{\mathrm{f}}=f_{\mathrm{m}}\left[1.2(\mathrm{EY}) \mathrm{NO}_{3}-N_{\text {credit }}\right]
$$

4. University of Missouri (Brown et al., 2004):

$$
N_{\mathrm{f}}=f_{\mathrm{m}}\left(0.9 \mathrm{EY}+4 P-20 f_{\mathrm{sOM}}-N_{\text {credit }}\right)
$$

where $f_{\mathrm{m}}$ is the unit conversion from pounds per acre to kilograms per hectare (1.119821), EY is expected yield (bu acre $\left.{ }^{-1}\right)$, $\mathrm{NO}_{3}$ is preplant (residual) soil $\mathrm{NO}_{3}-\mathrm{N}\left(\mathrm{lb}_{\mathrm{acre}}{ }^{-1}\right), \mathrm{SOM}$ is soil organic matter (\%), $D$ is the soil profile depth for soil $\mathrm{NO}_{3}$ measurement (assumed to be $61 \mathrm{~cm}$ in this study), $N_{\text {credit }}$ is $\mathrm{N}$ from sources not accounted for in the equation, including $\mathrm{N}$ credits from the previous crop, manure, irrigation water, and others, and $f_{\mathrm{SOM}}$ is the $\mathrm{N}$ credit from SOM determined based on Table A1. The $\mathrm{N}$ credit from the previous crop is $45 \mathrm{lb}$ acre $^{-1}$ for legumes and $0 \mathrm{lb}$ acre ${ }^{-1}$ for wheat (Triticum aestivum L.) and maize (previous crops pertinent to this study). The value of EY is estimated with the same approach as estimating the attainable yield in Maize-N, that is by assuming $Y_{\mathrm{a}}=$ $0.85 Y_{\mathrm{p}}$, where $Y_{\mathrm{p}}$ is the long-term yield potential simulated using the Hybrid-Maize model (Yang et al., 2004).

For each of these approaches (1-4), the EONR was determined by accounting for the ratio of maize grain to fertilizer $\mathrm{N}$ prices, following a method described by Dobermann et al. (2006b), that is by multiplying the $N_{\mathrm{f}}$ by the following price ratio factor:

$$
f_{\mathrm{R}}=1.311[1-\exp (-0.181 x)]
$$

where $x$ is price ratio of maize grain to $\mathrm{N}$ fertilizer in U.S. customary units (US\$ bu ${ }^{-1}$ maize/US $\$ \mathrm{lb}^{-1} \mathrm{~N}$ ). In this study, the maize grain price was US $\$ 0.1413 \mathrm{~kg}^{-1}$ (Economic Research Service, October 2009) and the N price was US\$0.831 kg-1 (adjusted to elemental $\mathrm{N}$ price from the actual price of $\mathrm{NH}_{4} \mathrm{NO}_{3}$, Economic Research Service, March 2009). The ratio of maize to $\mathrm{N}$ price was then equal to 0.170 in SI units (US\$ kg-1 maize/US $\$ \mathrm{~kg}^{-1} \mathrm{~N}$ ) or 9.5 in U.S. customary units $\left(\mathrm{US} \$ \mathrm{bu}^{-1}\right.$ maize/US $\left.\$ \mathrm{lb}^{-1} \mathrm{~N}\right)$.

\section{REFERENCES}

Blumenthal, J.M., D.J. Lyon, and W.W. Stroup. 2003. Optimal plant population and nitrogen fertility for dryland corn in western Nebraska. Agron. J. 95:878-883. doi:10.2134/agronj2003.0878

Broadbent, F.E., and A.B. Carlton. 1978. Field trials with isotopically labeled nitrogen fertilizer. p. 1-41. In D.R. Nielsen (ed.) Nitrogen in the environment. Academic Press, San Diego.

Brown, J.R., D.K. Crocker, J.D. Garret, R.D. Hanson, J.A. Lory, M.V. Nathan, P.C. Scharf, and H.N. Wheaton. 2004. Soil test interpretations and recommendation handbook. Univ. of Missouri, College of Agric., Div. of Plant Sci., Columbia.

Cassman, K.G., A. Dobermann, P.C. Sta Cruz, G.C. Gines, M.I. Samson, J.P. Descalsota, J.M. Alcantara, M.A. Dizon, and D.C. Olk. 1996. Soil organic matter and the indigenous nitrogen supply of intensive irrigated rice systems in the tropics. Plant Soil 182:267-278.

Cassman, K.G., A. Dobermann, and D.T. Walters. 2002. Agroecosystems, nitrogen-use efficiency, and nitrogen management. Ambio 31:132-140.

Dobermann, A., R.B. Ferguson, G.W. Hergert, C.A. Shapiro, D.D. Tarkalson, D.T. Walters, and C. Wortmann. 2006a. Should we abandon soil testing and yield goals in estimating nitrogen rates for corn? In Proc. North-Central Extension-Industry Soil Fertility Conf., 36th, Des Moines, IA. 7-8 Nov. 2006. Potash and Phosphate Inst., Brookings, SD.

Dobermann, A., R.B. Ferguson, G.W. Hergert, C.A. Shapiro, D.D. Tarkalson, D.T. Walters, and C.S. Wortmann. 2006b. Nitrogen response in highyielding corn systems of Nebraska. p. 50-59. In A.J. Schlegel (ed.) Proc. of the Great Plains Soil Fertility Conf., Denver, CO. 7-8 Mar. 2006. Kansas State Univ., Manhattan.

Dobermann A., C.S. Wortmann, R.B. Ferguson, G.W. Hergert, C.A. Shapiro, D.D. Tarkalson, and D.T. Walters. 2011. Nitrogen response and economics for irrigated corn in Nebraska. Agron. J. 103:67-75.

Economic Research Service. 2010a. Average U.S. farm prices of selected fertilizers, 1960-2010. USDA-ERS, Washington, DC.

Economic Research Service. 2010b. Commodity costs and returns data. USDAERS, Washington, DC.

Fageria, N.K., and V.C. Baligar. 2005. Enhancing nitrogen use efficiency in crop plants. Adv. Agron. 88:97-185. doi:10.1016/S0065-2113(05)88004-6

Gerwing, J., and R. Gelderman. 2005. South Dakota fertilizer recommendation guide. South Dakota State Univ. Coop. Ext. Serv., Brookings.

Grassini, P., J. Thornburn, C. Burr, and K.G. Cassman. 2011. High-yield irrigated maize in the western U.S. Corn Belt: I. On-farm yield, yield potential, and impact of agronomic practices. Field Crops Res. 120:142-152. doi:10.1016/j.fcr.2010.09.012

Inman, D., R. Khosla, D.G. Westfall, and R. Reich. 2005. Nitrogen uptake across site specific management zones in irrigated corn production systems. Agron. J. 97:169-176. doi:10.2134/agronj2005.0169

Janssen, B.H., F.C.T. Guiking, D. van der Eijk, E.M.A. Smalling, J. Wolf, and H. van Reuler. 1990. A system for quantitative evaluation of the fertility of tropical soils (QUEFTS). Geoderma 46:299-318. doi:10.1016/0016-7061(90)90021-Z

Janssen, P.H.M., and P.S.C. Heuberger. 1995. Calibration of process-oriented models. Ecol. Modell. 83:55-66. doi:10.1016/0304-3800(95)00084-9

Jones, C.A., and J.R. Kiniry. 1986. CERES-Maize: A simulation model of maize growth and development. Texas A\&M Univ. Press, College Station.

Kim, K.-I., D.E. Clay, C.G. Carlson, S.A. Clay, and T. Trooien. 2008. Do synergistic relationships between nitrogen and water influence the ability of corn to use nitrogen derived from fertilizer and soil? Agron. J. 100:551556. doi:10.2134/agronj2007.0064

Kitchen, N.R., K.A. Sudduth, S.T. Drummond, P.C. Scharf, H.L. Palm, D.F. Roberts, and E.D. Vories. 2010. Ground-based canopy reflectance sensing for variable-rate nitrogen corn fertilization. Agron. J. 102:71-84. doi:10.2134/agronj2009.0114 
Leikam, D.F., R.E. Lamond, and D.B. Mengel. 2003. Soil test interpretation and fertilizer recommendations. MF2586. Kansas State Univ., Manhattan.

Lory, J.A., and P.C. Scharf. 2003. Yield goal versus delta yield for predicting fertilizer nitrogen need in corn. Agron. J. 95:994-999. doi:10.2134/ agronj2003.0994

Lyon, D.J., G.L. Hammer, G.B. McLean, and J.M. Blumenthal. 2003. Simulation supplements field studies to determine no-till dryland corn population recommendations for semiarid western Nebraska. Agron. J. 95:884-891. doi:10.2134/agronj2003.0884

Moebius-Clune, B., H. van Es, and J. Melkonian. 2009. Adapt-N: An adaptive nitrogen management tool for corn production. Cornell Univ., Ithaca, NY.

Novoa, R., and R.S. Loomis. 1981. Nitrogen and plant production. Plant Soil 58:177-204. doi:10.1007/BF02180053

Olfs, H.W., K. Blankenau, F. Brentrup, J. Jasper, A. Link, and J. Lammel. 2005. Soil- and plant-based nitrogen-fertilizer recommendations in arable farming. J. Plant Nutr. Soil Sci. 168:414-431. doi:10.1002/jpln.200520526

Ping, J.L., R. Ferguson, and A. Dobermann. 2008. Site-specific nitrogen and plant density management in irrigated maize. Agron. J. 100:1193-1204. doi:10.2134/agronj2007.0174

Roberts, D. 2009. An integrated crop- and soil-based strategy for variable-rate nitrogen management in corn. Ph.D. diss. Univ. of Nebraska, Lincoln (Diss. Abstr. 3360163).

Scharf, P.C., S.M. Brouder, and R.G. Hoeft. 2006. Chlorophyll meter readings can predict nitrogen need and yield response of corn in the north-central USA. Agron. J. 98:655-665. doi:10.2134/agronj2005.0070
Setiyono, T.D., D. Walters, K.G. Cassman, C. Witt, and A. Dobermann. 2010. Estimating maize nutrient uptake requirements. Field Crops Res. 118:158-168. doi:10.1016/j.fcr.2010.05.006

Shapiro, C.A., R.B. Ferguson, G.W. Hergert, C.S. Wortman, and D.T. Walters. 2008. Fertilizer suggestions for corn. Univ. of Nebraska Ext. Serv., Lincoln.

Supit, I., and E. van der Goot. 2003. Updated system description of the WOFOST crop growth simulation model as implemented in the crop growth monitoring system, CGMS, applied by the European Commission. Treemail Publ., Heelsum, the Netherlands.

Timsina, J., M.L. Jat, and K. Majumdar. 2010. Rice-maize systems of South Asia: Current status, future prospects and research priorities for nutrient management. Plant Soil 335:65-82. doi:10.1007/ s11104-010-0418-y

van Groenigen, J.W., G.L. Velthof, O. Onema, K.J. van Groenigen, and C. van Kessel. 2010. Towards an agronomic assessment of $\mathrm{N}_{2} \mathrm{O}$ emissions: A case study for arable crops. Eur. J. Soil Sci. 61:903-913. doi:10.1111/j.1365-2389.2009.01217.x

Yang, H.S., A. Dobermann, J.L. Lindquist, D.T. Walters, T.J. Arkebauer, and K.G. Cassman. 2004. Hybrid-maize: A maize simulation model that combines two crop modeling approaches. Field Crops Res. 87:131-154. doi:10.1016/j.fcr.2003.10.003

Yang, H.S., and B.H. Janssen. 2000. A mono-component model of carbon mineralization with a dynamic rate constant. Eur. J. Soil Sci. 51:517-529. doi:10.1046/j.1365-2389.2000.00319.x 